\title{
INHIBITORY EFFECT OF EUGENOL ON RAT ILEAL MOTILITY IN VITRO
}

\author{
TRAILOVIĆ MS*, ROBERTSON PA** and NEDELJKOVIĆ-TRAILOVIĆ JELENA*
}

*University of Belgrade, Faculty of Veterinary Medicine, Serbia

${ }^{\star *}$ College of Veterinary Medicine, Department of Biomedical Sciences, lowa State University, IA, USA

(Recieved 2. December 2008)

Eugenol, an essential oil of clove oil possesses several different pharmacological properties, including antimicrobial, antifungal, insecticidal and antihelmintic. With regard to the digestive tract, eugenol has shown spasmolitic and relaxant effects. To elucidate some of the mechanisms involved, the effects of eugenol on contractions of isolated rat ileum induced by electrical field stimulation (EFS) were investigated. Eugenol (100 $\mu$ M) significantly and reversibly reduced EFS induced contractions by approximately $80 \%$. Control contractions were $2.00 \pm 0.18 \mathrm{~g}$, while contractions in the presence of eugenol decreased to $0.40 \pm 0.02 \mathrm{~g}(n=7 ; P=0.0001)$, respectively. Moreover, eugenol $(100 \mu M)$ reversibly decreased ileal basal tonus from $0.88 \pm 0.04 \mathrm{~g}$ to $0.65 \pm 0.04 \mathrm{~g}(n=7 ; P=0.0002)$.

After incubation with the nitric oxide synthase inhibitor nitro-Larginine methyl ester (L-NAME), eugenol $(100 \mu M)$ still significantly inhibited ileum contractions (reduction by $75.30 \%$ ), from $1.70 \pm 0.09 \mathrm{~g}$ to $0.42 \pm 0.08 \mathrm{~g}(n=6 ; P=0.0001)$, respectively. Likewise, incubation with L-NAME did not alter the eugenol relaxant effect on ileal basal tonus. Mean control basal tonus was $0.84 \pm 0.07 \mathrm{~g}$ and significantly decreased after the addition of eugenol $(100 \mu \mathrm{M})$, to $0.37 \pm 0.09 \mathrm{~g}(n=6$; $P=0.0003)$. After incubation with $300 \mu M$ of L-NAME mean basal tonus was $0.85 \pm 0.08 \mathrm{~g}$, while eugenol significantly relaxed ileal preparations in the presence of $L-N A M E$ to $0.34 \pm 0.11 \mathrm{~g}(n=6 ; P=0.0003)$.

Our results suggest that eugenol reversibly inhibits contractions caused by EFS and induces relaxation of rat ileum via a mechanism largely independent of NO activity.

Key words: eugenol, ileum, NO, L-NAME

\section{INTRODUCTION}

Eugenol, an aromatic substance is an essential oil and major component of clove oil (from Eugenia caryophllus). Eugenol is also found in large quantities in the essential oils of many other plants, most of them widely used in traditional folk medicine (Leal-Cardoso et al., 2002; Magalhaes et al., 2004). The frequent usage of different essential oils in folk medicine consequently increases the interest of 
investigators in their pharmacodynamic properties, as well as their mechanism of action.

Experimental studies have shown that eugenol appears to have several different pharmacological properties including antimicrobial, antifungal, insecticidal and antihelmintic actions (Burt, 2004; Pessao et al., 2002; López-Malo et al., 2002; Asha et al., 2001). On the other hand, many authors reported that this herbal medicine shows important relaxant properties in the blood vessels and smooth muscles in the digestive tract. Damiani et al. (2003) reported that eugenol causes relaxation of blood vessels smooth muscle through blockade of voltage and ligand dependent ion channels. In addition, according to Lahlou et al. (2004) i.v. treatment of both anesthetized and conscious rats with methyleugenol lowers blood pressure probably through active vascular relaxation.

With regard to the digestive tract, it has been shown that methyleugenol relaxes the isolated ileum and inhibits contractions induced by stimulation of voltage-dependent and receptor-operated channels (Lima et al., 2000).

Leal-Cardoso et al. (2002) showed that eugenol relaxes the basal tonus of the ileum precontracted with $\mathrm{KCl}$. In the same study authors reported that eugenol reversibly inhibited ileal contractions induced by submaximal concentrations of $\mathrm{ACh}$ and $\mathrm{K}^{+}$with IC50 values of approximately 228 and $237 \mu \mathrm{M}$. The relaxant effect of eugenol on basal tonus of the ileum precontracted with $\mathrm{KCl}$ was unaltered by tetrodotoxin, L-NAME, hexamethonium and indometacin.

In the present study, we decided to characterize the effects of eugenol in a smooth muscle preparation of rat's isolated ileum. While, it was interesting to study the effect of eugenol on contractions induced by electrical field stimulation in the isolated rat ileum, as well as a potential role of nitric oxide (NO) in the eugenol actions on gastrointestinal motility.

\section{MATERIAL AND METHODS}

Drugs

Eugenol (standardized in concentration of $95 \%$ in ethyl-alcohol) was a gift from Company ESSENTICO (commercial producer of eugenol in Serbia), and dissolved in ethanol, 10 and $100 \mu \mathrm{M}$ were tested. The volume added in the bath never exceeded $0.1 \%$ ethanol/25 mL and the contact time for both tested concentrations of eugenol before electrical stimulation was 2.5 minutes. Nitro-Larginine methyl ester (L-NAME) was purchased from Sigma (Italy), dissolved in distilled water and added to the bath $(0.1 \mathrm{~mL})$. Incubation time for each ileum preparation with L-NAME was 30 minutes prior to electrical stimulation.

\section{Animals}

Male Wistar rats, weighing 150-200 g, were housed under standard conditions for laboratory animals in groups of five with controlled 12-h light/dark cycles and temperatures between 21 and $24^{\circ} \mathrm{C}$. The day before the experiments, the animals were fasted overnight, but allowed ad libitum access to water. All procedures in the study conformed to EEC Directive 86/609. Rats were euthanized by cervical dislocation [in accordance with Home Office Code of 
Practice (1997). The Humane Killing of Animals under Schedule 1 to the Animals (Scientific Procedures) Act 1986. HMSO. ISBN 0-10-265397-6] and the abdomen was immediately opened. The segments of ileum (2 cm long) were removed and placed in Krebs solution $(\mathrm{mM}): \mathrm{NaCl} 139.9, \mathrm{KCl} 2.7, \mathrm{CaCl} 1.8, \mathrm{MgCl}_{2} 1.04$, $\mathrm{NaHCO}_{3} 11.9, \mathrm{NaH}_{2} \mathrm{PO}_{4} 0.4$ and glucose 5.5 at $37^{\circ} \mathrm{C}$.

\section{Procedures}

A segment of the ileum was placed in a longitudinal direction in a $25 \mathrm{~mL}$ muscle bath, filled with bubbled $\left(95 \% \mathrm{O}_{2} / 5 \% \mathrm{CO}_{2}\right) \mathrm{Krebs}$ solution at $37^{\circ} \mathrm{C}$. The upper end of the preparation was tied to an isotonic transducer (EI Unit, Belgrade, load $1.0 \mathrm{~g}$ ) connected to software PC Biodata-F (El Unit, Belgrade). After 30 minutes equilibration period, until a stable baseline was attained, preparations were subjected to electrical field stimulation by packages containing 5 stimulations every 60 seconds (EFS, $50 \mathrm{~Hz}$, for $2 \mathrm{sec}, 0.5$ ms pulse duration), with resting periods of 5 minutes between each package. EFS was delivered by electrodes placed around the preparation using a Narco Bio stimulator, (Systems Inc, Houston, USA). After stable control contractions evoked by EFS had been recorded (contractions were stable and reproducible for a period of at least 30 minutes), the responses were observed in the presence of different concentrations of eugenol and nitro-L-arginine methyl ester (L-NAME), a nitric oxide (NO) synthase inhibitor.

Statistical analyses

Results are expressed as means \pm SEM in grams (g) of contraction. Data were analyzed by Paired t-test, using GraphPad Prism, Version 4.0.

\section{RESULTS}

Eugenol significantly reduced contraction caused by EFS. Control contractions were $1.45 \pm 0.23 \mathrm{~g}$, while in the presence of $10 \mu \mathrm{M}$ eugenol, contractions decreased to $0.92 \pm 0.20 \mathrm{~g}(\sim 36 \%$ reduction) $(n=5 ; P=0.0056)$, respectively (Figure 1). The inhibitory effect of eugenol $(10 \mu \mathrm{M})$ on contractions caused by EFS were completely reversible; after washing contractions were not significantly different compared to initial control values. On the other hand, this concentration of eugenol did not have significant effects on amplitude and tonus of spontaneous ileal motor activity. Figure 2 shows representative recordings of eugenol inhibitory effects on EFS-induced contractions of rat ileum.

Higher concentrations of eugenol $(100 \mu \mathrm{M})$ caused a more pronounced inhibition of EFS-induced contractions $(\sim 80 \%)$; control contractions were $2.00 \pm 0.18 \mathrm{~g}$, while contractions in the presence of $100 \mu \mathrm{M}$ of eugenol were $0.40 \pm 0.02 \mathrm{~g}(\mathrm{n}=7 ; \mathrm{P}=0.0001)$, respectively (Figure 2 and 3$)$. Whereas, $10 \mu \mathrm{M}$ of eugenol had no effect on basal tonus of spontaneous ileum motor activity, higher concentrations $(100 \mu \mathrm{M})$ significantly decreased ileal basal tonus from control values of $0.88 \pm 0.04 \mathrm{~g}$ to $0.65 \pm 0.04 \mathrm{~g}$ after treatment $(\mathrm{n}=7 ; \mathrm{P}=0.0002)$. Likewise, this effect of eugenol was reversible and dissappeared after washing, basal tonus increased from $0.56 \pm 0.03 \mathrm{~g}$ to $0.84 \pm 0.05 \mathrm{~g}(\mathrm{n}=7 ; \mathrm{P}=0.002)$ (Figure 4). 


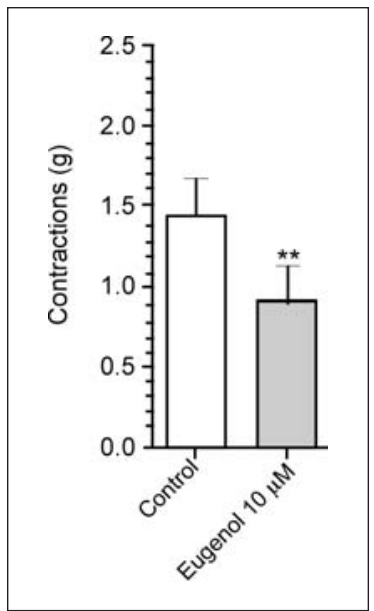

Figure 1. Inhibitory effect of eugenol $(10 \mu \mathrm{M})$ on contractions $(\mathrm{g})$ of isolated rat ileum caused by EFS (mean \pm SEM, $\mathrm{n}=5$, $\star \star-P=0.0056)$

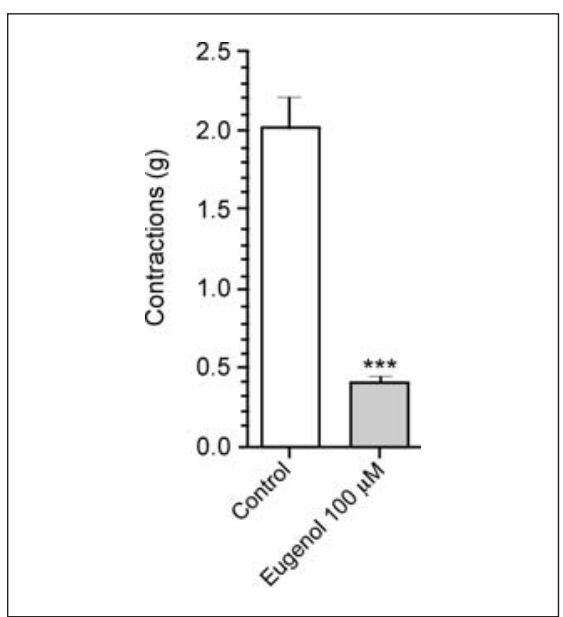

Figure 3. Inhibitory effect of eugenol $(100 \mu \mathrm{M})$ on contractions $(\mathrm{g})$ of isolated rat ileum caused by EFS (mean \pm SEM, $\mathrm{n}=7$, $\star * \star-P=0.0001)$

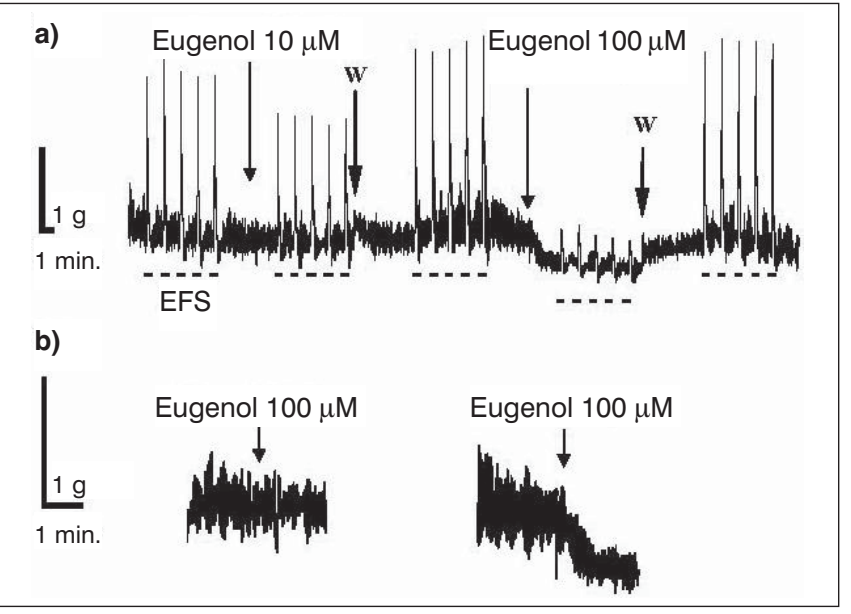

Figure 2. a) Tracing of rat ileal contractions caused by electrical field stimulation (EFS) in the presence of eugenol $(10 \mu \mathrm{M}$ and $100 \mu \mathrm{M})$;

b) Tracing of ileal basal tonus after application of eugenol (10 and $100 \mu \mathrm{M})$

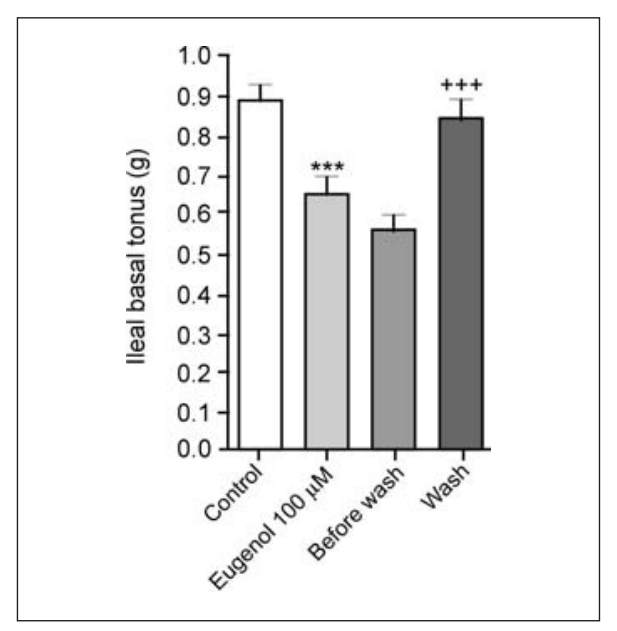

Figure 4. Relaxant effect of eugenol $(100 \mu \mathrm{M})$ on ileal basal tonus $(\mathrm{g})$ (mean \pm SEM, $n=7 ; * \star *-P=0.0002$ Control vs. eugenol; $+++-P=0.002$ Before washing and after 
Following control EFS and stimulations in the presence of eugenol $(100 \mu \mathrm{M})$, the same ileum preparations were incubated for 30 minutes with $300 \mu \mathrm{M}$ of L-NAME to examine the potential role of $\mathrm{NO}$ in the eugenol relaxant effect. The control contractions were $1.80 \pm 0.19 \mathrm{~g}$ while, in presence of eugenol $(100 \mu \mathrm{M})$ contractions significanly decreased, to $0.43 \pm 0.05 \mathrm{~g}(n=6 ; P=0.0008)$, respectively. Contractions of the same preparations, after 30 minutes incubation with $300 \mu \mathrm{M}$ of L-NAME were $1.70 \pm 0.09 \mathrm{~g}$, with no significant differences regarding control contractions $(P=0.8465)$. In the presence of L-NAME $(300 \mu \mathrm{M})$ eugenol $(100 \mu \mathrm{M})$ still significantly inhibits contractions (reduction of $75.30 \%$ ), being $0.42 \pm 0.08 \mathrm{~g}(n=6 ; P=0.0001)$ (Figure 5). The inhibitory effect of eugenol on ileum contractions caused by EFS was not significantly different after incubation with L-NAME. Likewise, incubation with $300 \mu \mathrm{M}$ of L-NAME did not influence the eugenol relaxant effect on ileal basal tonus. For these experiments mean control basal tonus was $0.84+0.07 \mathrm{~g}$ and significantly decreased after addition of eugenol $(100 \mu \mathrm{M})$ to $0.37+0.09 \mathrm{~g}(\mathrm{n}=6 ; \mathrm{P}=0.0003)$. After incubation with $300 \mu \mathrm{M}$ of L-NAME the mean basal tonus was $0.85+0.08 \mathrm{~g}$, while eugenol significantly relaxed ileal preparations in the presence of L-NAME to $0.34+0.11 \mathrm{~g}(\mathrm{n}=6$; $P=0.0003$ ), respectively (Figure 6). Figure 7 shows representative recordings of eugenol inhibitory effects on EFS-induced contractions and basal tonus of rat ileum before and after incubation with L-NAME (300 $\mu \mathrm{M})$.

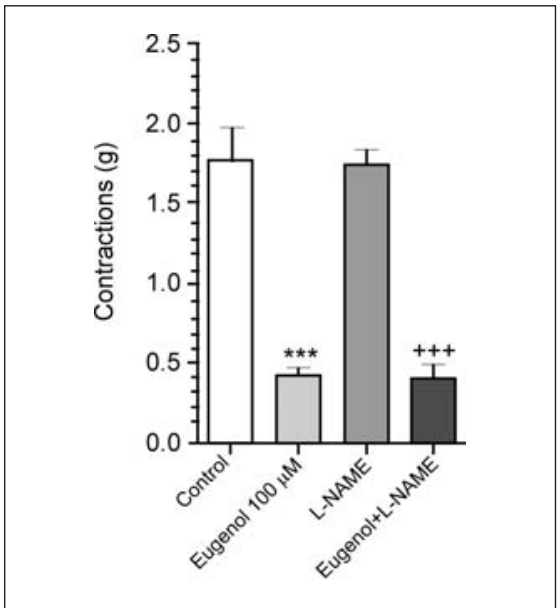

Figure 5. Inhibitory effect of eugenol $(100 \mu \mathrm{M})$ on contractions $(\mathrm{g})$ of the isolated rat ileum caused by EFS and the effect of eugenol on the same preparations after incubation with L-NAME $(300 \mu \mathrm{M})$ (mean \pm SEM, $n=6 ; * \star *-P=0.0008$ Control vs. eugenol;

$+++-P=0.0001$ L-NAME

vs. eugenol + L NAME)

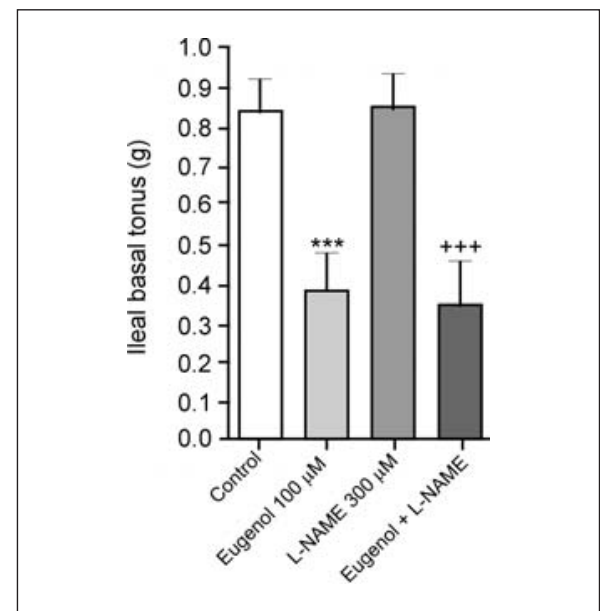

Figure 6. Relaxant effect of eugenol $(100 \mu \mathrm{M})$ on ileal basal tonus $(\mathrm{g})$ and the effect of eugenol after incubation with L-NAME $(300 \mu \mathrm{M})$ (mean \pm SEM, $\mathrm{n}=6$; $* \star \star *-\mathrm{P}=0.0003$ Control vs. eugenol; $+++-P=0.0003$ L-NAME vs. eugenol + L-NAME) 


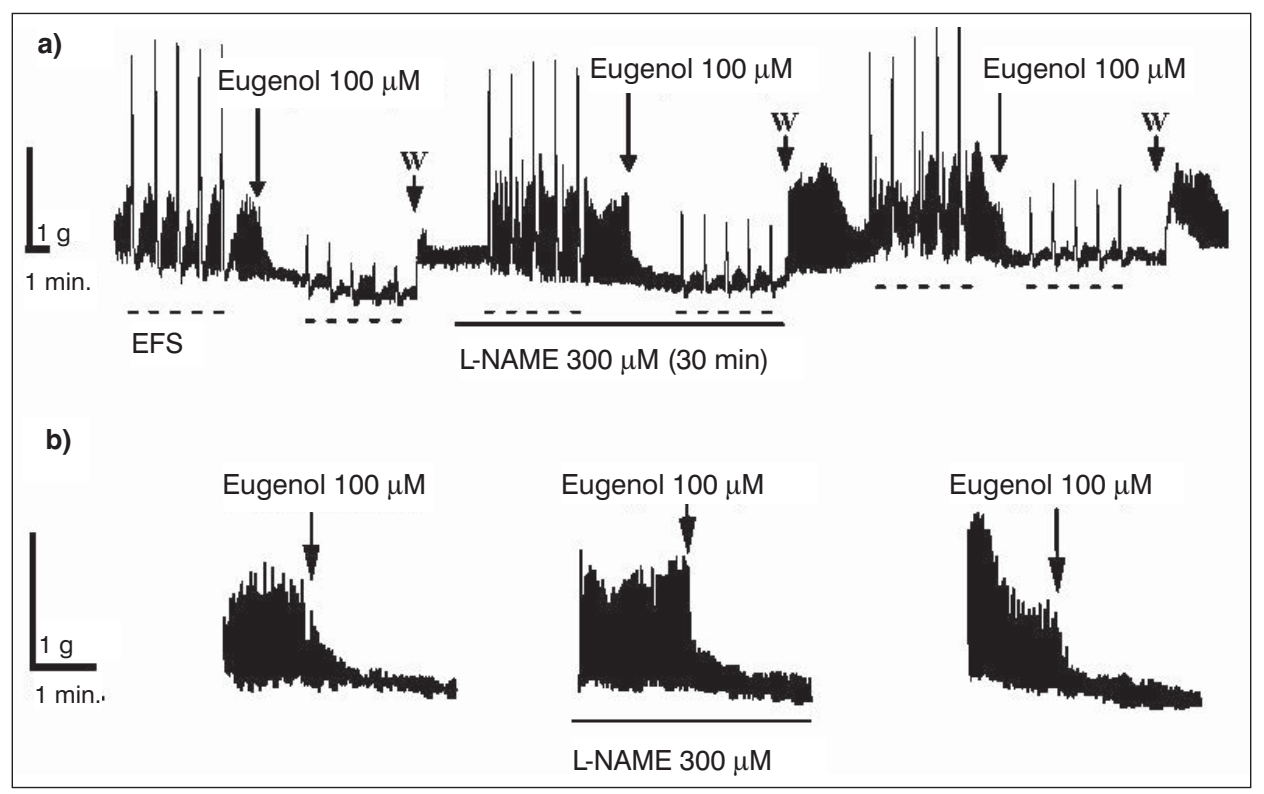

Figure 7. a) Tracing of rat ileal contractions caused by electrical field stimulation (EFS) in the presence of eugenol $(100 \mu \mathrm{M})$, before and after 30 minutes incubation with $\mathrm{L}$ NAME $(300 \mu \mathrm{M})$;

b) Tracing of ileal basal tonus after application of eugenol $(100 \mu \mathrm{M})$ before and after 30 minutes incubation with L-NAME $(300 \mu \mathrm{M})$

\section{DISCUSSION}

Our results show that eugenol is able to reduce the EFS-induced contractions in the rat isolated ileum. The highest tested concentration of eugenol $(100 \mu \mathrm{M})$, also significantly relaxes the ileal basal tonus. All noted effects of eugenol were completely reversible and disappeared after washing. Others have shown similar effects of eugenol and methyleugenol. Derived data in our investigation are in accordance with previously published results by Magalhaes et al. (2004) that essential oil from C. Nepetaefolius (which contains aboud $14.9 \%$ of methil-eugenol) inhibits ileum contractions induced by $\mathrm{ACh}$, histamine and $\mathrm{KCl}$. In this context Leal Cardoso et al. (2002) have reported that pure eugenol reversibly inhibited contractions induced by submaximal concentrations of acetylcholine (ACh) and $\mathrm{K}^{+}$with $\mathrm{IC}_{50}$ values of approximately 228 and $237 \mu \mathrm{M}$, respectively. NO is an established messanger in the gastrointestinal tract (Konturek and Konturek, 1995; Makhlouf and Grider, 1993; Stark and Szurszewski, 1992). NO either alone or with different cotransmitters is thought to mediate the inhibitory componet of the gut peristaltic wave. There is much evidence that different substances exert their relaxant effects in the gastrointestinal tract through interactions with NO in inhibitory enteric neurons (Ekblad and Sundel, 1997; Tanovic et al., 2001). Therefore, we tested the effect of eugenol on EFS-induced contractions of the 
ileum after incubation with L-NAME, an inhibitor of the nitric oxide synthase (NOS) enzyme. L-NAME is widely used for cardiovascular, gastrointestinal and other types of tissue. Its good water solubility makes it a popular experimental tool. In fact, L-NAME has been used in our investigation for studying the possible "nitrergic" involvement in the inhibitory and relaxant effects of eugenol on small intestine motility.

In our study the inhibitory effect of eugenol on contractions caused by EFS, as well as the relaxant effect on basal tonus of the ileum, were unaffected by LNAME, at doses used by other researchers to inhibit NOS-enzyme activity (Bartho et al., 1999; Teague et al., 2002). These results are in accordance with data published by Leal Cardoso et al. (2002), that the NO-synthase inhibitor L-NAME did not modify the relaxant effect of eugenol on ileum sections precontracted by $\mathrm{KCl}$. Eugenol relaxant effects on the ileal basal tonus has also been described.

Results from the present study indicate that eugenol has a significant inhibitory action on ileal basal tonus and contractions caused by EFS. Our results, together with previously mentioned data suggest that NO is not involved in the relaxant effect of eugenol on rat ileum. L-NAME does not influence eugenol inhibition of ileal contractions caused by EFS, nor eugenol induced relaxation of the ileal basal tonus. Moreover, all observed effects of eugenol regarding ileal motility are completely reversible. Others have shown that the eugenol inhibitory effect on ileal motility are independent of alterations of transmembrane potential and extracellular $\mathrm{Ca}^{2+}$ influx, as well as unaffected by sodium channel blocking agents (tetrodotoxin), ganglion blocking drugs (i.e. hexamethonium) and nonselective COX inhibitor (indomethacin). Our results together with previously published data suggest that eugenol induces reversible inhibition of EFS-caused contractions and causes relaxation of rat ileum probably by direct action on smooth muscle via a mechanism largely independent of NO activity.

\section{ACKNOWLEDGEMENTS:}

This work was supported by Serbian Ministry of Science and Environmental Protection, grant No 145026. We are grateful to Company ESSENTICO (Kula, Serbia) for the eugenol gift.

Address for correspondence:

Saša M. Trailović, DVM, PhD, Associate Professor

Department of Pharmacology and Toxicology

Faculty of Veterinary Medicine

University of Belgrade

Bulevar oslobodjenja 18

Belgrade 11000

Serbia

E-mail: sasa@vet.bg.ac.yu

\section{REFERENCES}

1. Asha MK, Prashanth D, Murali B, Padmaja R, Amit A, 2001, Anthelmintic activity of essential oil of Ocimum sanctum and eugenol, Fitoterapia, 72, 669-70.

2. Burt S, 2004, Essential oils: their antibacterial properties and potential applications in foods-a review, Int J Food Microbiol, 94, 3, 223-53. 
3. Damiani CEN, Rossioni LV, Vassallo DV, 2003, Vasorelaxant effect of eugenol on rat thoracic aorta, Vascul Pharmacol, 40, 59-66.

4. Ekblad E, Sundler F, 1998, Motor Responses in Rat lleum Evoked by Nitric Oxide Donors vs. Field Stimulation: Modulation by Pituitary Adenylate Cyclase-Activating Peptide, Forskolin and Guanylate Cyclase Inhibitors, JPET, 283, 23-8.

5. Konturek SK, Konturek PC, 1995, Role of nitric oxide in the digestive system, Digestion, 56,1, 1-13.

6. Lahlou S, Figueiredo AF, Magalhães PJ, Leal-Cardoso JH, Gloria PD, 2004, Cardiovascular effects of methyleugenol, a natural constituent of many plant essential oils, in normotensive rats, Life Sci, 74, 19, 2401-12.

7. Leal-Cardoso JH, Lahlou S, Coelho-de-Souza AN, Criddle DN, Pinto Duarte Gl, Santos MA et al, 2002, Inhibitory action of eugenol on rat isolated illeum, Can J Physiol Pharmacol, 80, 9, 901-6.

8. Lima CC, Criddle DN, Coelho-de-Souza AN, Monte FJ, Jaffar M, Leal-Cardoso JH, 2002, Relaxant and antispasmodic actions of methyleugenol on guinea-pig isolated ileum, Planta Med, 66, 5, 408-11.

9. López-Malo A, Alzamora SM, Palou E, 2002, Aspergillus flavus dose-response curves to selected natural and synthetic antimicrobials, Int J Food Microbiol, 73, 2-3, 213-8.

10. Magalhaes PJC, Lahlou S, Leal-Cadroso JH, 2004, Antispasmodic effect of the essential oil of Croton nepetaefolius on guinea-pig ileum: a myogenic activity, Fundam Clin Pharmacol, 18, 539-46.

11. Makhlouf GM, Grider JR, 1993, Nonadrenergic noncholinergic inhibitory transmitters of the gut, NIPS, 8, 195-9.

12. Pessoa LM, Morais SM, Bevilaqua CM, Luciano JH, 2002, Anthelmintic activity of essential oil of Ocimum gratissimum Linn. and eugenol against Haemonchus contortus, Vet Parasitol, 109, 1-2, 59-63.

13. Stark ME, Szurszewski JH, 1992, Role of nitric oxide in gastrointestinal and hepatic function and disease, Gastroenterology, 103, 1928-49.

14. Tanovic A, Jiménez M, Fernández E, 2001, Actions of NO donors and endogenous nitrergic transmitter on the longitudinal muscle of rat ileum in vitro: mechanisms involved, Life Sciences, $69,1143-54$.

15. Teague B, Asiedu S, Moore PM, 2002, The smooth muscle relaxant effect of hydrogen sulphide in vitro: evidence for a physiological role to control intestinal contractility, $\mathrm{Br} J$ Pharmacol, 137, 139-145.

\title{
INHIBITORNI EFEKT EUGENOLA NA MOTILITET ILEUMA PACOVA IN VITRO
}

\author{
TRAILOVIĆ SM, ROBERTSON AP i NEDELJKOVIĆ-TRAILOVIĆ JELENA
}

\section{SADRŽAJ}

Eugenol, aktivni princip ulja karanfilića, poseduje različita farmakološka svojstva, kao što su antimikrobno, antimikotičko, insekticidno i antihelmintičko. U digestivnom traktu deluje spazmolitički i relaksantno. U cilju bližeg upoznavanja mehanizma dejstva eugenola, ispitan je njegov efekt na kontrakcije iziolovanog ileuma pacova izazvane spoljnom stimulacijom (electrical field stimulation-EFS). Eugenol $(100 \mu \mathrm{M})$ signifikantno, reverzibilno redukuje kontrakcije ileuma izazvane EFS za oko $80 \%$. Kontrolne kontrakcije iznosile su 2,00 $\pm 0,18 \mathrm{~g}$, dok su kontrak- 
cije u prisutvu eugenola bile $0,40 \pm 0,02 \mathrm{~g}(\mathrm{n}=7 ; \mathrm{P}=0,0001)$. Eugenol $(100 \mu \mathrm{M})$, takođe signifikantno smanjuje i bazalni tonus izolovanog ileuma sa 0,88 $\pm 0,04 \mathrm{~g}$ na $0,65 \pm 0,04 \mathrm{~g}(\mathrm{n}=7 ; \mathrm{P}=0,0002)$.

Posle inkubacije sa ihibitorom sintaze azotnog oksida L-NAME, eugenol i dalje signifikantno redukuje kontrakcije ileuma (za 75,30\%) sa kontrolnih 1,70 \pm $0,09 \mathrm{~g}$ na $0,42 \pm 0,08 \mathrm{~g}(\mathrm{n}=6 ; \mathrm{P}=0,0001)$. Isto tako, inkubacija sa L-NAME ne utiče na relaksantni efekt eugenola na bazalni tonus ileuma. Kontrolna srednja vrednost bazalnog tonusa bila je $0,84 \pm 0,07 \mathrm{~g}$ i signifikantno je smanjena posle dodavanja eugenola $(100 \mu \mathrm{M})$ na $0,37 \pm 0,09 \mathrm{~g}(\mathrm{n}=6 ; \mathrm{P}=0,0003)$. Posle inkubacije sa $300 \mu \mathrm{M}$ L-NAME, srednji bazalni tonus bio je 0,85 $\pm 0,08 \mathrm{~g}$, dok je eugenol i u prisustvu L-NAME relaksirao izolovani ileum na $0,34 \pm 0,11 \mathrm{~g}(\mathrm{n}=6 ; \mathrm{P}=0,0003)$.

Dobijeni rezultati ukazuju da eugenol reverzibilno inhibiše kontrakcije ileuma izazvane spoljnom stimulacijom i dovodi do relaksacije izolovanog ileuma pacova mehanizmom nezavisnim od aktivnosti azotnog oksida. 